\title{
Sensory Test and Molecular Marker Based-Selection for Aromatic Rice in the $\mathrm{F}_{3}$ Progenies
}

\author{
Nono Carsono ${ }^{1 *}$, Amalia Purdianty ${ }^{2}$, Santika Sari ${ }^{1}$, and Citra Bakti ${ }^{1}$ \\ ${ }^{1}$ Lecturer in Faculty of Agriculture, Universitas Padjadjaran, Jatinangor, Bandung 40600, Indonesia. \\ ${ }^{2}$ Master Program, Majoring in Crop Breeding, Faculty of Agriculture, Universitas Padjadjaran, \\ Jatinangor, Bandung 40600, Indonesia. \\ *Author for correspondence: n.carsono@unpad.ac.id
}

\begin{abstract}
ABSTRAK
Uji Sensori dan Seleksi Berbasis Marka Molekuler untuk Karakter Aroma Pada Padi Keturunan Generasi $F_{3}$
\end{abstract}

Padi aromatik merupakan padi tipe khusus yang sangat disukai oleh masyarakat di Asia karena adanya aroma. Aroma di padi ditentukan oleh senyawa 2-acetyl-1-pyrroline (2AP) yang dikendalikan oleh gen resesif fgr. Persilangan antara kultivar Sintanur (padi aromatik) dan PTB33 (non-aromatik, tahan wereng coklat) telah dilakukan, guna mengembangkan galur padi aromatic yang tahan terhadap wereng coklat. Pada $\mathrm{F}_{2}$ hasil persilangan ini telah dilakukan seleksi berbasis marka molekuler dan bioassay untuk wereng coklat, akan tetapi seleksi untuk karakter aroma belum dilakukan khususnya di generasi $\mathrm{F}_{3}$ ini. Tujuan riset ini adalah untuk memperoleh individu padi galur F3 yang memiliki karakter aroma. Pengujian sensori dilakukan dengan menggunakan larutan $\mathrm{KOH}$ $1 \%$, untuk seleksi berbasis marka molekuler digunakan empat marka terkait, yaitu ESP (External Antisense Primer), IFAP (Internal Fragrant Antisense Primer), INSP (Internal Non fragrant Sense Primer) and EAP (External Antisense Primer). Delapan puluh delapan tanaman padi dari dua galur $\mathrm{F}_{3}$ (SP\#31 and SP\#224) hasil persilangan cv. Sintanur dan PTB33 telah diteliti. Deteksi dengan menggunakan marka molekuler diperoleh 75 genotipe $(85,23 \%)$ yang homosigot resesif aromatic dan satu heterosigot (non-aromatik). Delapan puluh lima (96,59\%) genotipe termasuk aromatik berdasarkan hasil uji sensori. Tujuh puluh dua $(81,82 \%)$ genotype termasuk aromatik berdasarkan uji sensory dan marka molekuler. Adanya inkonsistensi hasil dari kedua metode uji ini, maka disarankan untuk melakukan pengujian dengan menggunakan dua metode tersebut untuk menjamin kehandalan dan keakurasian karena aroma dipengaruhi oleh komposisi genetik dan kondisi lingkungan. Genotipe-genotipe yang terseleksi akan dilanjutkan untuk program pemuliaan guna mengembangkan padi aromatik dengan karakter agronomis yang lebih baik.

Keywords: EAP (External Antisense Primer), ESP (External Antisense Primer), IFAP (Internal Fragrant Antisense Primer), INSP (Internal Non Fragrant Sense Primer), Padi.

\begin{abstract}
Aromatic rice is a special type of rice that highly preferred by people in Asia due to the presence of aroma. Aroma in rice is determined by 2-acetyl-1-pyrroline (2AP) compound which is controlled by a recessive fgr gene. A hybridization between cv. Sintanur (aromatic rice) and PTB33 (non-aromatic, resistant to brown planthopper/BPH) has been done in order to develop aromatic rice lines that resistant to $\mathrm{BPH}$. In the $\mathrm{F}_{2}$ progeny, molecular marker-based selection and bioassay for the brown planthopper resistant lines have been carried out; however selection for the aromatic trait has not been performed yet. The objective of this study was to obtain the $F_{3}$ progeny's individual with aromatic trait. Sensory test was conducted by $\mathrm{KOH} 1.7 \%$ solution, meanwhile molecular markers applied were ESP (External Antisense Primer), IFAP (Internal Fragrant Antisense Primer), INSP (Internal Non fragrant Sense Primer) and EAP (External Antisense Primer). Eighty-eight plants from two selected (SP\#31 and SP\#224) F3 lines progenies derived from cv. Sintanur and PTB33 have been
\end{abstract}


evaluated in this study. Detection by molecular markers found seventy-five genotypes (85.23\%) were homozygous recessive (aromatic rice) and one was heterozygous (non-aromatic). Eighty-five (96.59\%) genotypes were aromatic as detected by sensory test alone. Seventy-two (81.82\%) genotypes were categorized as aromatic rice based on sensory test and molecular markers. Due to inconsistency results from each method alone, it is advised both methods to be applied to ensure the reliability and the accuracy since aroma in rice is affected by genetic composition and environment conditions. Selected genotypes will be continued for breeding program in developing aromatic rice with improved agronomic traits.

Keywords: EAP (External Antisense Primer), ESP (External Antisense Primer), IFAP (Internal Fragrant Antisense Primer), INSP (Internal Non Fragrant Sense Primer), Rice

\section{INTRODUCTION}

Aromatic rice is more preferred by farmers because it has a higher selling price in local as well as international markets as compared to nonaromatic one (Giraud, 2013). Therefore, it is necessary to develop the suitable breeding methods for aromatic rice in order to fulfill the consumer's demand and increase the farmer's income due to the increase demand for local and international markets. According to Buttery et al. (1983), 2-acetyl-1pyrroline (2AP) is the key for the aromatic compound in rice. This compound could be found in all plant parts except roots (Lorieux et al., 1996; Yoshihashi et al., 2002). Expression of this compound can be observed through sensory test (Yoshihashi et al., 2002) and detection it with molecular markers (Bradbury et al., 2005).

The sensory test of aromatic in rice can be performed by using solution of KOH 1.7\% (Sood \& Siddiq, 1978), meanwhile the molecular markers using a specific marker (Bradbury et al., 2005) which is closely linked to the for gene that controlled the expression of aromatic trait. The $f g r$ gene in rice is located on chromosome 8 (Jin et al., 2010). The previous study was carried out using $\mathrm{F}_{3}$ progeny from a cross of Sintanur x PTB-33 (SP). Sintanur is original variety from Indonesia with many valuable traits including aromatic trait (Balitpa, 2001), meanwhile PTB33 is originally from India and have a high resistance to brown planthopper/BPH (Rongbei et al., 2001). The objective of this hybridization was to create new genotypes having both aromatic and resistant to BPH traits in one single genotype. In the $\mathrm{F}_{2}$ progeny, molecular marker-based selection for the BPH resistant had been carried out and obtained some promising lines (Carsono et al., 2016), however selection for aromatic trait has not been performed yet. There is a limited report regarding the effort in integrating aromatic and $\mathrm{BPH}$ resistance traits into one single genotype. Jairin et al. (2009) has reported in obtaining cv. Khao Dawk Mali 105 (KDML105), Thai aromatic rice cultivar with improved $\mathrm{BPH}$ resistance trait, which focused on the improvement of $\mathrm{BPH}$ resistance, not aromatic trait. Therefore, evaluation of $\mathrm{F}_{3}$ progenies for aromatic trait is important to be conducted in order to obtain rice genotypes having both aromatic and brown planthopper resistance traits.

\section{MATERIALS AND METHODS \\ Plant materials}

Eighty eight genotypes of $\mathrm{F}_{3}$ progeny derived from a crossing between Sintanur and PTB33 were evaluated, consisted of forty six genotypes derived from line SP\#224 and forty two were from line SP\#31. All genotypes have been identified as resistant to BPH based on SSR (Simple Sequence Repeats) molecular markers in the $\mathrm{F}_{2}$ progeny (Carsono et al., 2016). Seeds from these geneotypes were germinated and grown in the screen house of Experimental Station, Faculty of Agriculture, Universitas Padjadjaran, Jatinangor Campus. The leaves from every genotype were collected at the heading stage for the sensory test and DNA analysis.

\section{Sensory test for aromatic detection}

The aromatic test was conducted with 10 panelists using $\mathrm{KOH} 1.7 \%$ solutions. The test was done by inserting leaf pieces from plant $(1.5 \mathrm{~g})$ into the tube with $1.5 \mathrm{ml}$ of $\mathrm{KOH} 1.7 \%$ and it was left there for 30 minutes. The aroma identification was performed by smelling the aroma in the tube then classified based on the presence or absence of aroma. All individual genotypes (88 plants) were scored for sensory test. 


\section{DNA extraction and PCR amplification}

DNA extraction from young leaves was performed by CTAB method (Doyle \& Doyle, 1987) with a slight modification in amount of sample and ethanol for DNA precipitation. DNA quality was analyzed using gel electrophoresis by using $2 \%$ agarose gel that dissolved in $100 \mathrm{ml}$ of $0.5 \mathrm{x}$ TBE. The solution then was heated in a microwave for 2 minutes at the $150^{\circ} \mathrm{C}$. Electrophoresis was done at 80 Volt for 45-60 min., and then it soaked in $\mathrm{EtBr}$ (ethidium bromide) solution for $30 \mathrm{~min}$. and in distilled water for 10 minutes. DNA quantity measurement was done by measuring the concentration of DNA at a wavelength of $260 \mathrm{~nm}$ and $280 \mathrm{~nm}$ in spectrophotometer PCR was performed for molecular marker assessment for aromatic and non-aromatic rice in a total volume of $10 \mu \mathrm{l}$, consisted of $1 \mu \mathrm{l}$ of genomic DNA $20 \mathrm{ng} / \mu \mathrm{l}, 5$ $\mu \mathrm{l}$ KAPA Taq DNA polymerase, and $1 \mu$ of each primer. Four specific markers were used according to Bradburry, 2005) i.e.: TTGTTTGGAGCTTGCTGATG; (ESP: external sense primer), CATAGGAGCAGCTGAAATATATACC (IFAP: internal fragrant antisense primer), CTGGTAAAAAGATTATGGCTTCA (INSP: internal non fragrant sense primer) and AGTGCTTTACAAAGTCCCGC (EAP: external antisense primer). Cycling conditions were an initial denaturation of $95^{\circ} \mathrm{C}$ for $5 \mathrm{~min}$. followed by 35 cycles of $1 \mathrm{~min}$. at $95^{\circ} \mathrm{C}, 1 \mathrm{~min}$. at $58^{\circ} \mathrm{C}, 1 \mathrm{~min}$. at $72^{\circ} \mathrm{C}$; and a final extension of $72^{\circ} \mathrm{C}$ for $5 \mathrm{~min}$. PCR products were analyzed using electrophoresis $(2.0 \%$ agarose gel, and $1 \mathrm{~kb}$ ladder) and ethidium bromide stained $(0.5 \mu \mathrm{g} / \mathrm{ml})$.

\section{RESULTS AND DISCUSSION}

Aromatic and non-aromatic rice lines derived from hybridization between Sintanur and PTB33 were studied in order to distinguish these lines.The results showed that aromatic and nonaromatic rice can be detected using $1.7 \% \mathrm{KOH}$ test (Sood \&Siddiq, 1978) and specific primers (Bradbury et al., 2005). It was recorded as (+) for aromatic and (-) for non-aromatic (Table 1). Visualization of molecular marker for aromatic and non-aromatic detection is presented in Fig. 1.

In this study, 85 genotypes (96.59\%) were selected as aromatic rice by sensory test, 75 genotypes $(85.23 \%)$ by molecular markers
(Bradburry's primer), and 72 genotypes $(81.82 \%)$ by both methods (Table 1). Twelve genotypes (13.64\%) have been detected as aromatic rice based on sensory test; however they were not confirmed by molecular markers (Table 1). It means that homozygous recessive lines (aa, aromatic) were not detected, only homozygous dominant (AA, nonaromatic) and heterozygous (Aa, non-aromatic) were found. In total 12 plants, out of 88 , or around $13.64 \%$ (Table 2) which is much higher compared to the opposite condition (sensory negative, molecular markers positive) i.e., $3.41 \%$ or 3 rice plants. False positive plants identified by sensory test were higher than those confirmed by molecular markers $(13.65 \%$ versus $3.41 \%$ ).

This finding is in accordance data presented by Yeap et al. (2013) who found around $30-40 \%$ of $F_{1}$ rice population detected were non-fragrant rice but they expressed aroma in their leaves and grains. In addition Alrufaye et al. (2018) found the same thing, two genotypes, out of 16 genotypes were not detected by molecular markers but they expressing aroma. This condition may be due to the present other aromatic compound as revealed by Pachauri et al. (2010) stated that a significant variation in the type and intensity of aroma in the different groups of aromatic rice varieties, suggesting involvement of additional chemical compounds in varying proportions or Fitzgerald et al. (2008) argued that any other fgr gene controlling aroma in rice. Other explanation, this condition might be due to reduction of smell ability of panelists, so that they could not distinguish between scent of aromatic and non-aromatic compound. It could be also that there were allegations of minor genes that controlling rice aroma (Alrufaye et al., 2018).

Singh et al. (2007) reported that besides badh 2 gene on chromosome 8 , there is also badh 1 gene on chromosome 4 as a candidate gene controlling the scent because it has the same function as badh2 gene on chromosome 8. The badh2 gene is also detected on chromosome 3, although badh2 on chromosome 8 had a major influence for phenotypic variation of aroma. So that, it is possible if the genotypes are detected by sensory test, but not by molecular marker. Other it might be that $\mathrm{KOH}$ solution may cause damage to the olfactory senses, so it can reduce the ability of panelists in analysis (Hien et al., 2006). 
Table 1. Identification of aromatic and non-aromatic rice plants by both sensory and molecular markers.

\begin{tabular}{|c|c|c|c|c|c|c|c|c|c|c|c|}
\hline No. & Sample & $1.7 \% \mathrm{KOH}^{\mathrm{a}}$ & Molecular Marker ${ }^{\mathrm{a}}$ & No. & Sample & $1.7 \% \mathrm{KOH}$ & Molecular Marker & No. & Sample & $1.7 \% \mathrm{KOH}$ & Molecular Marker \\
\hline 1 & SP31-2 & + & + & 31 & SP31-34 & + & + & 61 & SP224-19 & + & + \\
\hline 2 & SP31-3 & - & + & 32 & SP31-35 & + & + & 62 & SP224-20 & + & + \\
\hline 3 & SP31-5 & + & - & 33 & SP31-36 & + & - & 63 & SP224-21 & + & + \\
\hline 4 & SP31-6 & + & + & 34 & SP31-37 & + & + & 64 & SP224-22 & + & + \\
\hline 5 & SP31-7 & + & + & 35 & SP31-38 & + & + & 65 & SP224-23 & + & + \\
\hline 6 & SP31-8 & + & - & 36 & SP31-39 & - & + & 66 & SP224-25 & + & + \\
\hline 7 & SP31-9 & + & + & 37 & SP31-40 & + & + & 67 & SP224-26 & + & + \\
\hline 8 & SP31-10 & + & - & 38 & SP31-41 & + & + & 68 & SP224-27 & + & + \\
\hline 9 & SP31-11 & + & + & 39 & SP31-42 & + & - & 69 & SP224-28 & + & + \\
\hline 10 & SP31-12 & + & + & 40 & SP31-43 & + & - & 70 & SP224-29 & + & + \\
\hline 11 & SP31-13 & + & - & 41 & SP31-44 & + & + & 71 & SP224-30 & + & + \\
\hline 12 & SP31-14 & + & - & 42 & SP31-45 & + & - & 72 & SP224-31 & + & + \\
\hline 13 & SP31-15 & + & + & 43 & SP224-1 & + & + & 73 & SP224-32 & + & + \\
\hline 14 & SP31-16 & + & + & 44 & SP224-2 & + & + & 74 & SP224-33 & + & + \\
\hline 15 & SP31-17 & + & + & 45 & SP224-3 & + & + & 75 & SP224-34 & + & + \\
\hline 16 & SP31-18 & + & + & 46 & SP224-4 & + & + & 76 & SP224-35 & + & + \\
\hline 17 & SP31-19 & + & + & 47 & SP224-5 & + & + & 77 & SP224-36 & + & + \\
\hline 18 & SP31-20 & + & - & 48 & SP224-6 & + & + & 78 & SP224-37 & + & + \\
\hline 19 & SP31-21 & - & + & 49 & SP224-7 & + & + & 79 & SP224-38 & + & + \\
\hline 20 & SP31-22 & + & + & 50 & SP224-8 & + & + & 80 & SP224-39 & + & + \\
\hline 21 & SP31-23 & + & - & 51 & SP224-9 & + & + & 81 & SP224-40 & + & + \\
\hline 22 & SP31-24 & + & + & 52 & SP224-10 & + & + & 82 & SP224-41 & + & + \\
\hline 23 & SP31-25 & + & + & 53 & SP224-11 & + & + & 83 & SP224-42 & + & + \\
\hline 24 & SP31-26 & + & + & 54 & SP224-12 & + & + & 84 & SP224-43 & + & + \\
\hline 25 & SP31-27 & + & + & 55 & SP224-13 & + & + & 85 & SP224-44 & + & + \\
\hline 26 & SP31-28 & + & + & 56 & SP224-14 & + & + & 86 & SP224-45 & + & + \\
\hline 27 & SP31-29 & - & - & 57 & SP224-15 & + & + & 87 & SP224-46 & + & + \\
\hline 28 & SP31-30 & + & + & 58 & SP224-16 & + & + & 88 & SP224-47 & + & + \\
\hline 29 & SP31-31 & + & + & 59 & SP224-17 & + & + & & & & \\
\hline 30 & SP31-33 & + & - & 60 & SP224-18 & + & + & & & & \\
\hline
\end{tabular}

Note: ${ }^{\text {a }}(+)$ : Aroma, (-): Non-aroma 


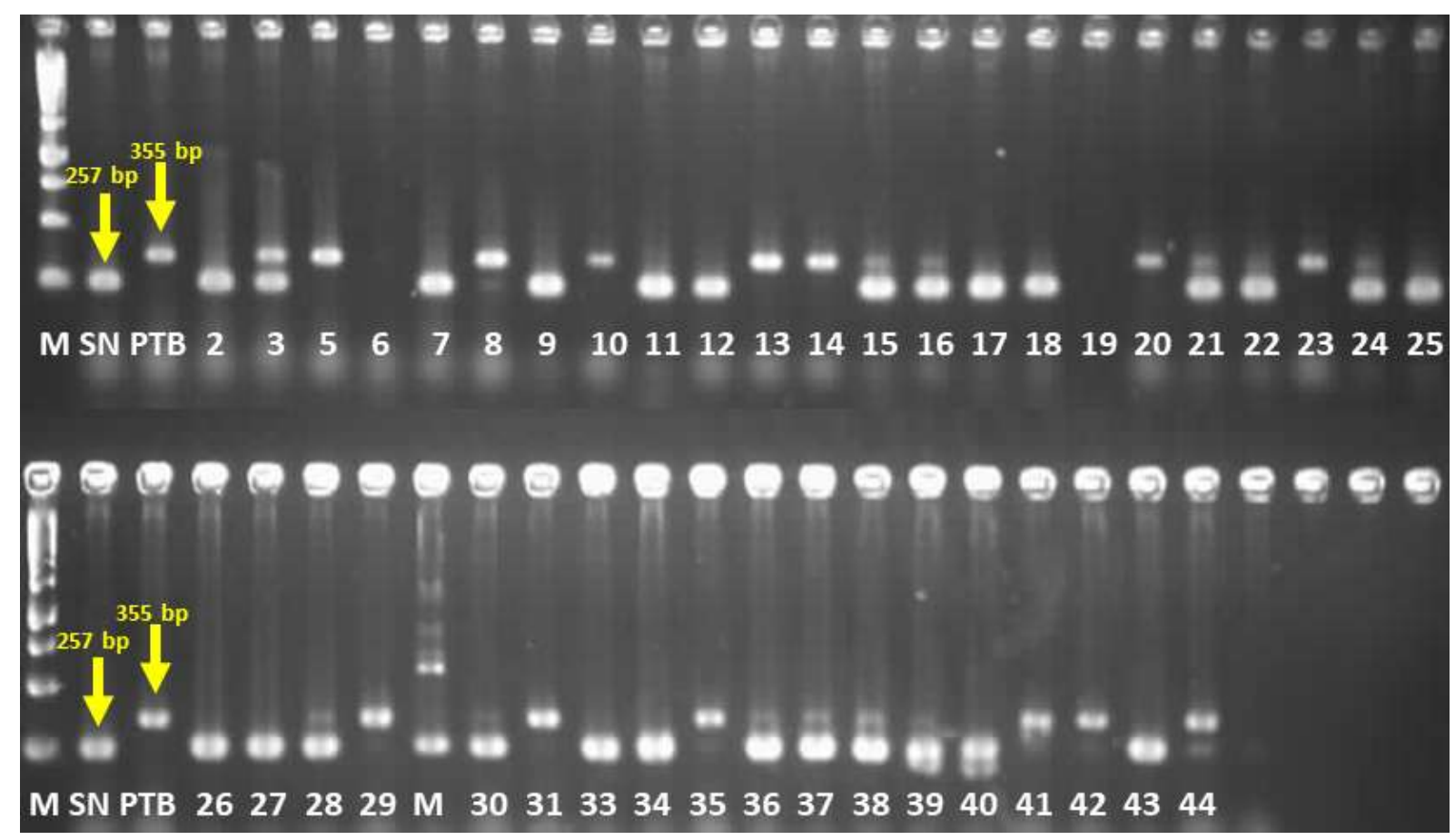

Fig 1. Visualization of molecular markers to distinguish aromatic (257bp) and non-aromatic rice (355bp). Remarks: M= ladder; SN: Cv. Sintanur; PTB= PTB33; Number represents genotype number of F3 progeny.

Table 2. Detection of aroma by sensory test and molecular markers in leaf tissues for $88 \mathrm{~F}_{3}$ progeny derived from the hybridization between Sintanur and PTB33.

\begin{tabular}{|c|c|c|c|c|}
\hline \multirow[b]{2}{*}{ Result } & \multicolumn{2}{|c|}{$F_{3}$ segregants $^{\mathrm{a}}$} & \multirow{2}{*}{$\begin{array}{c}\text { Number of } F_{3} \\
\text { segregants }\end{array}$} & \multirow[b]{2}{*}{ Percentage (\%) } \\
\hline & Sensory test ${ }^{\mathrm{a}}$ & Molecular markers ${ }^{\mathrm{b}}$ & & \\
\hline Positive for both & & & & \\
\hline $\begin{array}{l}\text { sensory and } \\
\text { molecular markers }\end{array}$ & + & + & 72 & 81.8 \\
\hline Recombination & + & - & 12 & 13.6 \\
\hline Recombination & + & $\mathrm{H}$ & 0 & 0.0 \\
\hline Recombination & - & + & 2 & 2.3 \\
\hline Recombination & - & $\mathrm{H}$ & 1 & 1.1 \\
\hline $\begin{array}{l}\text { Negative for both } \\
\text { sensory and } \\
\text { molecular markers }\end{array}$ & - & - & 1 & 1.1 \\
\hline & \multicolumn{2}{|c|}{ Total number of plants } & 88 & 100 \\
\hline
\end{tabular}

a For sensory test: (+): Aroma detected; (-): Non-aroma.

${ }^{\mathrm{b}}$ For molecular markers: (+): homozygous recessive (aa); (-): homozygous dominant (AA); H: Heterozygous (Aa).

On the other hand, three genotypes were confirmed as aromatic rice based on molecular markers (aa, homozygous recessive) but not expressing aroma as detected by sensory test (Table 1 and 2). This might be due to the very low intensity of the 2-acetyl-1-pyrroline (2AP) detected in the genotypes, so it cannot be captured by the panelist. Singh (2000) argued that the strength of aroma or the concentration of 2AP might be affected by environmental conditions. For example, rice cv. Basmati will be strong in aromatic scent if the temperature is relatively cool during growing period in the day $\left(25-32^{\circ} \mathrm{C}\right)$ and night $\left(20-25^{\circ} \mathrm{C}\right)$ with humidity of $70-80 \%$ during flowering and grain filling period. 
Prodhan et al. (2017) mentioned that cultivation practice, genetic composition, environmental condition and its interaction affect the aroma quality in rice and they also confirmed that among environmental components, temperature is a vital component that can affect the aroma quality and chemical composition of aromatic rice.

From those information, it is clear that aroma in rice is affected by genetic composition and environmental condition. Thus, breeding for high quality aroma and cultivation methods that support aromatic expression is important to be done. However due to the effect of environment factors in evaluating aroma in segregating population $\left(\mathrm{F}_{3}\right)$, integration of sensory methods and molecular marker will provide more accurate and reliable result for determining some promising genotypes should be continued for the next generation.

\section{CONCLUSION}

Eighty eight plants from two selected (SP\#31 and SP\#224) $\mathrm{F}_{3}$ lines progenies derived from cv. Sintanur and PTB33 have been evaluated in this study. Seventy two (81.82\%) genotypes were categorized as aromatic rice based on sensory test and molecular markers. Seventy five (85.23\%) genotypes carried homozygous recessive gene (aromatic rice) and one genotype was heterozygous detected by molecular markers. Eighty five (96.59\%) genotypes were detected by sensory test alone. Due to inconsistency results from each method alone, it is advised both method to be applied to ensure the reliability and accuracy since aroma in rice is affected by genetic composition and environment conditions.

\section{REFERENCES}

Alrufaye, TAUH, BAHAL Khafaji, WMS Al-sheikh. 2018. Use molecular markers analysis and sensory methods in the revelation of fragrance in Iraqi rice. J. Pharm. Sci. and Res. 10 (10): 2531-2533.

Balitpa (Balai Penelitian Padi). 2001. Padi aromatic varietas Sintanur. Departemen Pertanian, Agdex 112/37. (in Bahasa Indonesia).

Bradburry, LMT, RJ Henry, Q Jin, RF Reinke, and DLE Waters. 2005. A perfect marker for fragrance genotyping in rice. Molecular Breeding, 16 (4):279-283. doi: 10.1007/s11032-005-0776-y.
Buttery, RG, LC Ling, OB Juliano, and JG Turnbaugh. 1983. Cooked rice aroma and 2acetyl-1-pyrroline. Journal of Agricultural and Food Chemistry. 31:823-826.

Carsono, N, GI Prayoga, N Rostini, and D Dono. 2016. Molecular marker based selection on $\mathrm{F}_{2}$ progeny for developing promising rice lines resistant to brown planthopper (in Bahasa Indonesia). Jurnal Agrikultura 27 (1): 9-15. Doi: 10.24198/agrikultura.v27i1.8471

Doyle, JF, and JL Doyle. 1987. A rapid DNA isolation procedure for small quantities of fresh leaf tissue. Phytochemical Bulletin. 19 (1): 11-15.

Giraud, G. 2013. The world market of fragrant rice, main issues and perspectives. International Food and Agribusiness Management Review. 16 (2): 1-20.

Fitzgerald, MA, NRS Hamilton, MN Calingacion, and VM Butardo. 2008. Is there a second fragrance gene in rice. Plant Biotechnology Journal. 6: 416-423.

Hien, NL, T Yoshihashi, WA Sahardi, VC Thanh, Y Oikawa, and Y Hirata. 2006. Evaluation of aroma in rice (Oryza sativa L.) using $\mathrm{KOH}$ method, molecular markers, and measurement of 2-Acetyl-1-Pyrroline concentration. Journal of Tropical Agriculture. 50(4):190-198, 2006.

Jairin, J, S Teangdeerith, P Leegalud, J Kothcharerk, $\mathrm{K}$ Sansen, $\mathrm{M}$ Yi, A Vanavichit, and $\mathrm{T}$ Toojinda. 2009. Development of rice introgression lines with brown plant hopper resistance and KDML105 grain quality characteristics through marker assisted selection. Field Crop Res. 110:263-271.

Jin L, Y Lu, Y Shao, G Zhang, P Xiao, S Shen, H Corke, and J Bao. 2010. Molecular marker assisted selection for improvement of the eating, cooking and sensory quality of rice (Oryza sativa L.). Journal of Cereal Science. 51:159-164.

Lorieux, M, M Perov, N Huang, E Guiderdoni, and A. Ghesquiere. 1996. Aroma in rice genetic analysis of a quantitative trait. Theoretical and Applied Genetics. 93:1145-1151.

Pachauri, V, MK Singh, AK Singh, S Singh, NA Shakeel, VP Singh, and Singh NK. 2010. Origin and genetic diversity of aromatic rice varieties, molecular breeding and chemical and genetic basis of rice aroma. Journal of 
Plant Biochemistry \& Biotechnology 19 (2):127-143.

Prodhan, ZH, G. Faruq, KA Rashid and RM Taha. 2017. Effects of temperature on volatile profile and aroma quality in rice. International Journal of Agriculture and Biology. 19: 1065-1072. DOI:10.17957/IJAB/15.0385.

Rongbei L, Q Xueyi, W Sumei, MP Pandey, and PK Pathak. 2001. Inheritance of resistance to brown planthopper in an Oryza rufipogon (Griff.)-derived line in rice. Current Science. 80:1421-1423.

Singh, R, AK Singh, TR Sharma, A Singh, and NK Singh. 2007. Fine mapping of aroma QTLs in Basmati rice (Oryza sativa L.) on chromosomes 3, 4 and 8. Journal of Plant Biochemistry and Biotechnology. 16 (2):7582.
Singh, VP. The Basmati rice of India. 2000. p.135153. In Sing, RK, US Singh and GS Kush (Eds). Aromatic Rices. Oxford \& IBH Publ. Co. Pvt. Ltd. New Delhi, India.

Sood, BC, and EA Siddiq. 1998. A rapid technique for scent determination in rice. Indian Journal of Genetics and Plant Breeding. 38:268-271.

Yeap, HY, G Faruq, HP Zakaria, and JA Harikrishna. 2013. The efficacy of molecular markers analysis with integration of sensory methods in detection of aroma in rice. The Scientific World Journal: 1-6. http://dx.doi.org/10.1155/2013/569268.

Yoshihashi, T, NTT Huong, and N Kabaki. 2002. Quality evaluation of Khao Dawk Mali 105, an aromatic rice cultivar of Northeast Thailand. JIRCAS Working Report No. 30:150-160. 